\title{
STRUKTUR DAN POLA KOMUNIKASI DALAM WACANA PEMBELAJARAN TEKS EKSPLANASI DI MADRASAH ALIYAH AL-ISTIQOMAH
}

\author{
Ari Wahyuni ${ }^{* 1}$, Dian Eka Chandra Wardhana ${ }^{2}$, Agus Trianto ${ }^{3}$ \\ ${ }^{1,2,3}$ Program Studi Magister Pendidikan Bahasa Indonesia, FKIP, Universitas Bengkulu \\ Jalan W.R. Supratman Kandang Limun, Kota Bengkulu, Indonesia \\ Email: ariwahyuw55@gmail.com ${ }^{* 1}$, dec.wardhana@unib.ac.id ${ }^{2}$, agustrianto@unib.ac.id ${ }^{3}$
}

\begin{abstract}
Abstrak
Pembelajaran wacana teks eksplanasi dapat dilihat berhasil atau tidaknya mengantarkan siswa mencapai tujuan pembelajaran bahasa dengan cara mengkaji struktur dan pola komunikasinya. Untuk itu, tujuan penelitian ini adalah untuk mendeskripsikan struktur dan pola komunikasi dalam wacana pembelajaran teks eksplanasi di Madrasah Aliyah Al-Istiqomah. Metode penelitian menggunakan model analisis wacana kelas dengan model IRF. Subjek penelitian ini berjumlah 21 siswa. Teknik pengumpulan data dilakukan dengan observasi, perekaman, dan wawancara. Teknik analisis wacana menggunakan analisis wacana kelas Sinclair dan Coulthard dengan model IRF yaitu initiation, response, dan follow-up. Uji keabsahan data menggunakan triangulasi teknik pengumpulan data. Hasil penelitian menunjukkan bahwa dalam melakukan pembelajaran teks eksplanasi, struktur wacana kelas pada pembelajaran tidak selalu berstruktur IRF pada pertukaran bebas. Sedangkan pada pertukaran terikat fungsi $\mathrm{F}$ tidak hanya menjadi balikan, namun disertai inisiasi ulang atau terikat (Ib) sehingga struktur wacana kelasnya menjadi I R Ib R F/lb R. Pola komunikasi yang terjadi dalam pembelajaran terdiri dari dua pola, yaitu pola komunikasi sebagai interaksi dan pola komunikasi transaksi.
\end{abstract}

Kata kunci: struktur wacana, pola komunikasi, pembelajaran teks eksplanasi

\section{THE STRUCTURE AND PATTERN OF COMMUNICATION IN THE TEACHING OF EXPLANATORY TEXT DISCOURSE IN MADRASAH ALIYAH AL-ISTIQOMAH}

\begin{abstract}
Learning explanatory text discourse can be seen whether it is successful or not in bringing students to achieve the goals of language learning by examining the structure and patterns of communication. For this reason, the purpose of this study is to describe the structure and patterns of communication in the discourse of explanatory text learning at Madrasah Aliyah AlIstiqomah. The research method used a class discourse analysis model with the IRF model. The subjects of this study were 21 students. Data collection techniques are carried out by observation, recording, and interviews. Discourse analysis technique uses discourse analysis class Sinclair and Coulthard with the IRF model, namely initiation, response, and follow-up. Data validity test used triangulation of data collection techniques. The results showed that in learning explanatory text, the structure of classroom discourse in learning was not always structured with IRF in free exchange. Whereas in bound exchange, the function of $F$ is not only reversed, but accompanied by re-initiation or bonding (Ib) so that the class discourse structure becomes IR lb RF / lb R. transaction communication.
\end{abstract}

Keywords: discourse structure, communication patterns, explanatory text learning 


\section{A. Pendahuluan}

Analisis wacana kelas pada pembelajaran, khususnya pembelajaran bahasa Indonesia perlu dikembangkan lebih luas untuk mengetahui seluruh aspek pendukung yang terdapat dalam pengembangan pembelajaran. Objek kajian analisis wacana adalah penggunaan bahasa beserta konteksnya selaras dengan pendapat Darma (2009:4) dan Apreno \& Noermanzah (2020:93) bahwa analisis wacana mengkaji bahasa secara terpadu, dalam arti tidak terpisah-pisah seperti dalam linguistik, semua unsur bahasa terikat pada konteks pemakainya.

Analisis wacana kelas digunakan untuk mengetahui interaksi dan komunikasi pada proses pembelajaran di kelas. Analisis ini bertujuan untuk mengetahui struktur wacana kelas beserta pola komunikasi yang terjadi dalam pembelajaran di kelas (Handayani dkk., 2020:109). Penelitian mengenai analisis wacana kelas pernah dilakukan oleh Atkins (2001:1) dan hasil penelitiannya tersebut menyajikan pembahasan mengenai model Sinclair and Coulthard's untuk pembelajaran di kelas terkecil yaitu dengan subjek satu siswa. Selain itu, penelitian ini juga menyajikan hasil analisis dan efektivitas tentang pengembangan model untuk analisis kelas ukuran terkecil pada pembelajaran bahasa Inggris (pembelajaran privat).

Penelitian serupa juga pernah dilakukan oleh White (2003:2), dalam penelitian ini menggunakan model serupa untuk mendeskripsikan interaksi antara guru-murid dalam berbicara yang dikembangkan oleh Sinclair dan Coulthard (1975, 1992) dan menerapkan skala peringkatnya ke sebuah sampel data wacana kelas yang direkam dari pembelajaran pengajaran pribadi atau dengan kata lain pembelajaran pada les privat. Namun, subjek penelitian ini hanya melibatkan satu orang saja dalam pembelajaran privat. Hal ini akan berbeda jika penerapannya melibatkan subjek penelitian lebih dari satu orang terutama jika di terapkan di kelas dengan jumlah yang lebih banyak dan situasi yang kompleks.

Pembelajaran bahasa yang berbasis teks akan memiliki tingkat pemahaman tersendiri bagi peserta didik. Sebagian peserta didik yang belum terlatih untuk mahir membaca, maka dia akan kesulitan saat dituntut untuk mereproduksi sebuah teks. Ada beberapa teks yang dipelajari di kelas XI yaitu: 
teks prosedur, teks eksplanasi, teks ceramah, cerita pendek, dan lain-lain. Penelitian mengenai kemampuan menulis juga pernah diteliti oleh Normawati (2017:234) dengan judul penelitian Kemampuan Menulis Teks Eksplanasi Siswa Kelas XI IPA2 SMA Negeri 1 Sentani Kabupaten Jayapura. Hasil dari penelitian ini menyatakan bahwa berdasarkan penilaian terhadap lima aspek kemampuan menulis teks eksplanasi dengan skala penilaian kualitas tulisan, sampel penelitian pada umumnya belum menunjukkan kemampuan menulis teks eksplanasi yang memuaskan.

Pembelajaran bahasa Indonesia dalam pengaplikasiannya akan membutuhkan media pembelajaran. Adanya media pembelajaran diharapkan mampu menjadi jembatan interaksi dan membangun pola komunikasi yang intens antar guru dan siswa dalam pembelajaran (Noermanzah dkk., 2018:116). Berdasarkan infomasi dari guru yang mengajar Mata Pelajaran Bahasa Indonesia sebelumnya, pembelajaran berbasis teks ini hanya dilakukan menggunakan media buku teks saja. Guru menyampaikan materi, setelah itu memberikan latihan kepada siswa menulis teks. Sebatas itulah proses pembelajarannya. Oleh karena itu penulis ingin melihat hasil pemahaman informasi berupa pengetahuan dan urutan kejadian dari yang didengar atau dibaca menggunakan media pembelajaran berupa komputer.

Analisis wacana kelas dalam pelaksanaan pembelajaran di kelas khususnya pada pembelajaran bahasa Indonesia menjadi salah satu kompetensi guru dalam mendeskripsikan hasil dari proses pembelajaran yang berlangsung. Namun, saat ini belum banyak tenaga pendidik yang melakukan analisis ini pada pembelajaran yang mereka terapkan. Seperti analisis yang disampaikan peneliti sebelumnya, analisis ini bertujuan untuk mendeskripsikan keseluruhan proses interaksi dan komunikasi dalam pembelajaran. Penelitian mengenai analisis wacana kelas pada pembelajaran teks eksplanasi ini perlu dilakukan. Hal ini bertujuan untuk mendeskripsikan hasil analisis wacana kelas pembelajaran teks eksplanasi di MA Al-Istiqomah dilihat dari struktur wacana dan pola komunikasi yang terjalin dalam proses pembelajaran. 
Penelitian mengenai analisis wacana kelas juga pernah diteliti oleh Wirma \& Suryadi (2017:193) dengan hasil analisis yang diperoleh yaitu, guru menggunakan bahasa Indonesia yang berfungsi sebagai bahasa pengantar keilmuan atau pendidikan. Dalam melaksanakan proses belajar mengajar tersebut, ada faktor utama yang harus diketahui oleh guru salah satunya adalah interaksi antara guru dan siswa. Adapun interaksi yang dimaksud adalah analisis wacana interaksi kelas berdasarkan ruang lingkup penelitian yang meliputi transaksi, pertukaran, dan tindak.

Sementara penelitian mengenai wacana kelas lain dilakukan oleh Saptani (2015:8) dengan hasil penelitian berupa data yang dominan yang berupa tindak tutur yang ditemukan tidak cukup menonjol sebagai data primer yang menjadi penguatan pembelajaran. Tindak tutur yang dominan digunakan guru adalah tindak tutur arahan (directive), pancingan (elicitation), balasan (reply), dan penunjukan (nomination) tindak tutur ini lebih mengarah pada kegiatan tanya jawab atau bahkan diskusi dalam pembelajaran dan penunjukkan pada nama siswa untuk meminta respons. Pada kedua penelitian ini, peneliti menganalisis wacana sebatas wacana lisan yang terjadi dalam interaksi pembelajaran di dalam kelas. Sementara struktur wacana kelas dan pola komunikasi, belum mereka teliti lebih lanjut. Selain itu, media yang digunakan dalam penelitian sebelumnya berbeda dengan pembelajaran yang akan dilaksanakan oleh peneliti.

Dari uraian mengenai latar belakang masalah tersebut, penelitian akan mengkaji masalah struktur wacana kelas dan pola komunikasi dalam pembelajaran teks eksplanasi, diharapkan dapat memotivasi guru untuk lebih memahami segala aspek yang bisa dioptimalkan untuk keberhasilan dalam proses pembelajaran. Harapannya akan ada pembaharuan hasil belajar siswa dalam menulis teks eksplanasi. Permasalahan yang akan dibahas pada penelitian ini adalah "Bagaimanakah struktur dan pola komunikasi dalam wacana pembelajaran teks eksplanasi di Madrasah Aliyah Al-Istiqomah? Dengan tujuan mendeskripsikan struktur dan pola komunikasi dalam wacana pembelajaran teks eksplanasi di Madrasah Aliyah Al-Istiqomah. 


\section{B. Metode Penelitian}

Metode yang digunakan dalam penelitian ini adalah metode analisis wacana menggunakan model analisis wacana kelas dengan model IRF (initiation, response, follow-up) Sinclair dan Coulthard dalam (Atkins, 2001:1). Penelitian ini dilakukan di Madrasah Aliyah Al-Istiqomah Jl. Pattimura. Desa, Bumi Makmur. Kecamatan, Nibung. Kabupaten Musi Rawas Utara. Pada Kelas XI tahun ajaran 2019/2020. Penelitian dilakukan pada tanggal 20 Januari dan 21 Januari 2020.

Data penelitian ini berupa segala aspek yang ada dan terlibat dalam proses pembelajaran. Sumber data dalam penelitian ini adalah interaksi antara guru dan siswa dalam proses pembelajaran teks eksplanasi siswa kelas XI MA AlIstiqomah tahun ajaran 2019/2020. Dengan jumlah 21 siswa sebagai subyek penelitian dan menggunakan perangkat komputer sebagai media pembelajaran.

Data penelitian ini dikumpulkan dengan teknik observasi, dan wawancara. Observasi atau pengamatan merupakan suatu teknik atau cara mengumpulkan data dengan jalan mengadakan pengamatan terhadap kegiatan yang sedang berlangsung (Sukmadinata, 2008:216). Dalam hal ini peneliti hanya melakukan pengamatan dalam proses belajar-mengajar yang sedang berlangsung dan tidak ikut dalam kegiatan belajar mengajar, peneliti hanya melihat dan mendengarkan saja.

Perekaman dilakukan untuk menyimpan data karena data pada penelitian ini berupa data visual dan audio visual sebagai data yang nantinya akan dijadikan landasan penelitian. Perekaman dilakukan ketika memulai pembelajaran hingga proses pembelajaran selesai. Perekaman berupa rekaman audio visual. Perekaman tersebut dilakukan untuk mengambil data asli dan juga digunakan sebagai dokumentasi data. Alat yang digunakan untuk merekam adalah Sony Hndycam DCR-SX65E dengan optical zoom 60X.

Wawancara digunakan sebagai teknik pengumpulan data apabila peneliti ingin melakukan studi pendahuluan untuk menemukan permasalahan yang harus diteliti, tetapi juga apabila peneliti ingin mengetahui hal-hal dari respondens yang lebih dalam (Sugiyono, 2018:193). Analisis data dilakukan dengan mengikuti langkah-langkah analisis penelitian kualitatif Miles dan Huberman dalam 
(Sugiyono, 2018:132) secara garis besar Miles dan Huberman membagi komponen analisis data dalam penelitian kualitatif ke dalam tahap-tahap berikut yaitu, pengumpulan data, reduksi data, penyajian data, dan penarikan kesimpulan/verifikasi.

Kegiatan untuk pada setiap penelitian adalah pengumpulan data. Pengumpulan data dilakukan dengan melakukan observasi langsung, wawancara, dan merekam proses pembelajaran. Berikutnya, reduksi data, data yang diperoleh di lapangan cukup banyak, untuk itu perlu dicatat secara teliti dan rinci. Mereduksi data berarti merangkum, memilih hal-hal yang pokok, memfokuskan pada hal-hal yang penting, dicari tema dan polanya. Dalam mereduksi data, setiap peneliti akan dipandu oleh teori dan tujuan yang akan dicapai. Tujuan utama dari penelitian kualitatif adalah temuan.

Penyajian data (display data). Pada tahap ini, setelah data direduksi langkah selanjutnya adalah mendisplay data. Dalam penelitian kualitatif, penyajian data bisa dilakukan dalam bentuk uraian singkat, bagan, hubungan antar kategori, flowchart, dan sejenisnya. Yang paling sering digunakan untuk menyajikan data dalam penelitian kualitatif adalah dengan teks yang bersifat naratif. Dalam penelitian ini penyajian data ditampilkan dalam bentuk tabel hasil analisis wacana kelas dalam bentuk struktur dan pola komunikasi wacana kelas.

Kesimpulan dalam penelitian kualitatif merupakan temuan baru yang sebelumnya belum pernah ada. Verifikasi dimaksudkan untuk menghasilkan kesimpulan yang valid. Oleh karena itu, peneliti melakukan peninjauan ulang terhadap kesimpulan dengan cara memverifikasi kembali catatan-catatan selama penelitian.

Keabsahan data di uji dengan uji credibility atau uji kepercayaan menggunakan triagulasi. Triangulasi diartikan sebagai teknik pengumpulan data yang bersifat menggabungkan dari berbagai teknik pengumpulan data dan sumber data yang telah ada. Triangulasi yang digunakan adalah triangulasi teknik. Triangulasi teknik berarti saat melakukan penelitian, peneliti menggunakan teknik pengumpulan data yang yang berbeda-beda untuk mendapatkan data dari sumber yang sama (Sugiyono, 2018:125). Pada penelitian ini data diperoleh dengan 
observasi lapangan (lingkungan sekolah), wawancara mendalam pada guru yang mengajar bahasa Indonesia, dan dokumentasi dengan cara merekam suara dan visual dalam proses pembelajaran. Uji keabsahan data ini dilakukan oleh guru bahasa Indonesia, peneliti serta pembimbing penyusunan tesis sekaligus sebagai ahli dalam bidang analisis wacana kelas.

\section{Hasil Penelitian dan Pembahasan}

\section{Hasil Penelitian}

\section{a. Struktur Wacana Kelas dalam Pembelajaran Teks Eksplanasi}

Analisis wacana kelas terdiri dari struktur yang tersusun secara hierarki, struktur tersebut terdiri dari pelajaran (lesson), transaksi (transaction), pertukaran (excange), gerak (move) dan tindak (act). Pada proses pembelajaran, transaksi terdiri dari kegiatan awal pembelajaran, kegiatan inti dan kegiatan penutup pembelajaran.

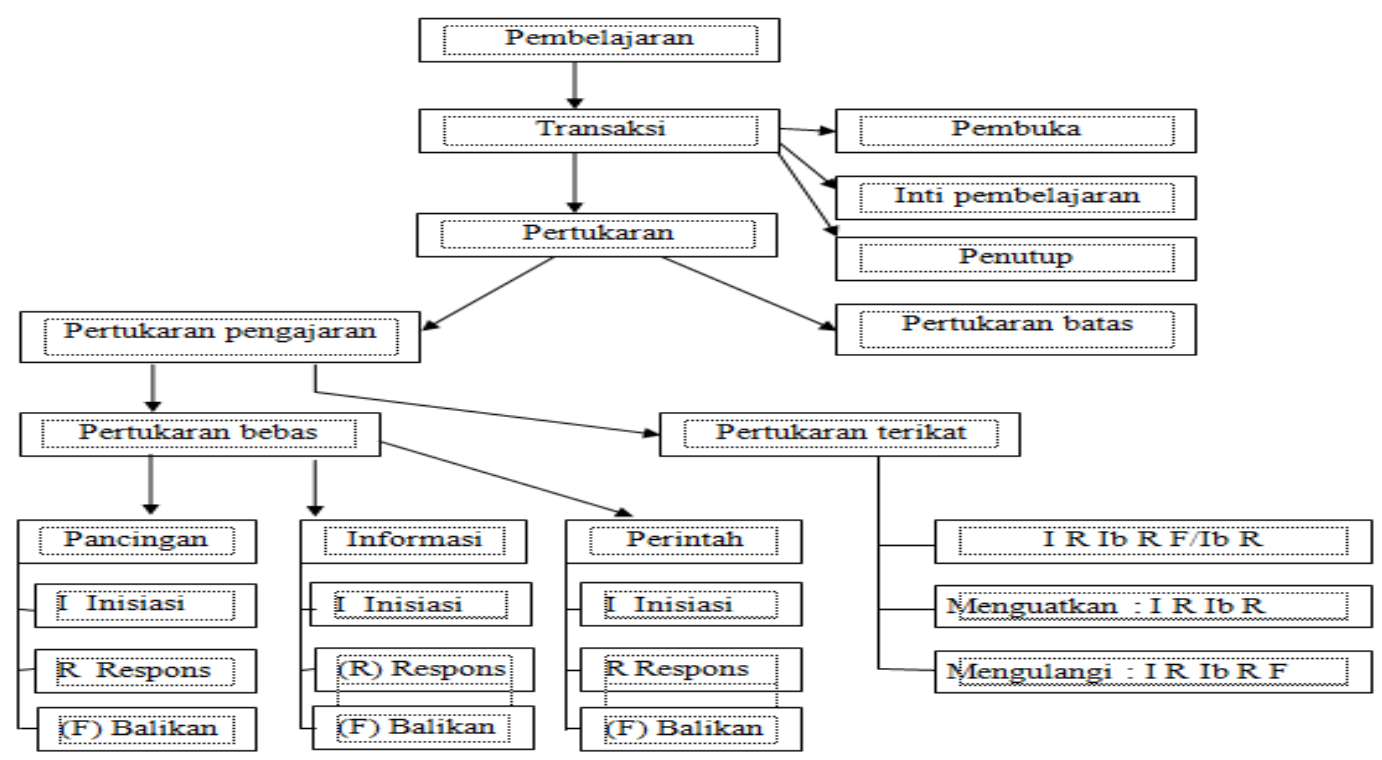

Gambar 1. Struktur Wacana Kelas Pembelajaran Teks Eksplanasi

\section{b. Pola Komunikasi dalam Wacana Kelas}

Pola komunikasi yang terjalin dalam proses pembelajaran terdiri dari dua jenis yaitu pola komunikasi dua arah dan juga pola komunikasi banyak arah. Sedangkan pola komunikasi satu arah, tidak terjadi dalam proses pembelajaran. Hal ini dikarenakan, setiap kali guru selesai memberikan informasi, arahan 
ataupun pancingan siswa bersedia menjawab pertanyaan atau menganggapi pernyataan yang disampaikan oleh guru.

1) Pola Komuniasi Dua Arah

Pola komunikasi jenis bisa dilihat hampir di setiap pertukaran bebas antara siswa dan guru. Misalnya pada pertukaran bebas dari ketiga kategori yang disampaikan di atas. Selalu ada timbal balik komunikasi antara siswa dan guru dalam melakukan interaksi di dalam pembelajaran, tetapi jumlah siswa yang terlibat interaksi dengan guru tersebut hanya satu atau individual, tidak terhubung dengan siswa lain dalam berinteraksi. Contohnya pada pertukaran bebas kategori menginformasikan. Guru memberikan informasi dan direspons oleh siswa, sebaliknya saat siswa yang memberikan informasi guru juga meresponsnya.

2) Pola Komunikasi Banyak Arah

Pola komunikasi dalam bentuk pertukaran terikat, memiliki peluang terjadinya pola komunikasi ini. Yaitu terlihat hubungan timbal balik antara guru dan siswa, namun siswa juga memiliki hubungan komunikasi dengan siswa lain di saat yang bersaman. Komunikasi inilah yang akan menjadikan siswa aktif dalam proses pembelajaran. Pola komunikasi ini biasanya dijumpai dalam diskusi, namun tidak menutup kemungkinan saat tanya jawab juga bisa dilakukan.

Pertukaran komunikasi banyak arah juga dengan guru berinteraksi dengan satu siswa, namun siswa-siswa lain ikut menyampaikan pendapatnya sehingga komunikasi berjalan pada banyak arah antara guru dan siswa, serta dari siswa ke siswa lain. Dalam pertukaran yang terjalin juga dapat dilihat adanya pemakaian bahasa daerah.

Gerak yang dilakukan dalam pembelajaran meliputi menginisiasi, merespons dan memberikan umpan balik atau balikan. Inisiasi bisa dilakukan oleh guru dan juga dilakukan oleh siswa begitu juga dengan respons dan balikan. Sedangkan tindak yang merupakan unit terkecil dari struktur analisis wacana, diklasifikasikan menjadi tiga yang sesuai jenisnya yaitu meta-interactive acts, interactive acts dan turn-taking acts Coulthard dalam (Nicholson, 2014:213) dan 22 berdasarkan kategorinya dengan rincian data sebagai berikut. 
Tabel 1. Frekuensi Tindak Tutur dalam Pembelajaran

\begin{tabular}{|c|c|c|c|}
\hline No. & Jenis Tindak Tutur & Guru & Siswa \\
\hline \multicolumn{4}{|c|}{ Tindak Metainteraktif } \\
\hline 1. & Kesimpulan (con) & 3 & - \\
\hline 2. & Ulangan (I) & 5 & - \\
\hline 3. & Penanda (m) & 3 & - \\
\hline 4. & Metastetmen (ms) & 1 & - \\
\hline 5. & Tekanan Diam $\left(^{\wedge}\right)$ & 3 & - \\
\hline \multicolumn{4}{|c|}{ Tindak Interaktif } \\
\hline 6. & Menerima (acc) & 4 & - \\
\hline 7. & Mengakui (ack) & 1 & - \\
\hline 8. & Memeriksa (ch) & 3 & - \\
\hline 9. & Petunjuk (cl) & 3 & - \\
\hline 10. & Komentar (com) & - & 4 \\
\hline 11. & Arahan (d) & 8 & 1 \\
\hline 12. & Pancingan (el) & 27 & 8 \\
\hline 13. & Penilaian (e) & 10 & 3 \\
\hline 14. & Percepatan $(p)$ & 3 & - \\
\hline 15. & Reaksi (rea) & 3 & 5 \\
\hline 16. & Balasan (rep) & 5 & 55 \\
\hline 17. & Informatif (i) & 13 & 1 \\
\hline \multicolumn{4}{|c|}{ Tindak Pergantian Peran } \\
\hline 18. & Isyarat (cu) & 8 & 35 \\
\hline 19. & Tawaran (b) & - & 8 \\
\hline 20. & Penunjukan (n) & 5 & - \\
\hline 21 & Permulaan (s) & 10 & - \\
\hline \multicolumn{4}{|c|}{ Lainnya } \\
\hline 22. & Kesamping (z) & - & - \\
\hline
\end{tabular}

Dari data tabel 1 dapat dilihat bahwasannya tindak yang paling sering dilakukan oleh guru adalah tindak permulaan, pancingan, informatif, dan penilaian. Sedangkan tindak yang paling dominan dilakukan oleh siswa adalah membalas atau menjawab,menggunakan insyarat atau bahasa nonverbal dan tawaran. Dari 35 isyarat yang digunakan siswa ini terbagi kedalam 7 jenis tindak, diantaranya adalah mengangkat tangan dengan tanpa respons linguistik, mengangkat tangan lalu bertanya, mengangkat tangan untuk menjawab pertanyaan dari guru, menganggukkan kepala, menggelengkan kepala, menunjuk sesuatu menggunakan jari telunjuk, membuka kelima jari tangan berupa indikator mempersilakan. Dari 22 kategori tindak tutur yang disampaikan Sinclair dan Coulthard dalam (Nicholson, 2014:213) ada satu yang sama sekali tidak ada dalam transkrip proses pembelajaran.

Silampari Bisa: Jurnal Penelitian Pendidikan Bahasa Indonesia, Daerah, dan Asing Vol. 3, No. 2, 2020 


\section{Pembahasan}

\section{a. Struktur Wacana Kelas dalam Pembelajaran Teks Eksplanasi}

Proses pembelajaran diawali dengan transaksi lalu dilanjutkan adanya pertukaran yang dapat berupa diskusi dan tanya jawab. Baik terjadi antara siswa dan guru, maupun terjadi antara siswa dan siswa yang lain. Pertukaran ini terbentuk dari beberapa gerak dan tindak, baik berupa perilaku, kegiatan atau tindakan lain yang terjadi dalam kelass pada proses pembelajaran.

Proses pembelajaran di kelas tidak terlepas dari adanya percakapan dan interaksi dari guru dan siswa dalam pertukaran pembelajaran. Dalam pertukaran ini guru dan siswa melakukan sesi tanya jawab dan juga diskusi. Pada kegiatan tanya jawab struktur partisipasi akan dapat berubah sesuai dengan kondisi pembelajaran di dalam kelas. Apakah pembukaan pembicaraan diperankan oleh guru ataukah malah diperankan oleh siswa. Guru mengajukan pertanyaan, yang menghasilkan tanggapan (respons) siswa. Siswa menanggapi dengan menjawab pertanyaan tersebut. Lalu guru memberikan umpan balik atau balikan pada siswa yang menanggapi pertanyaan tersebut. Namun, struktur ini terkadang tidak selalu seperti itu.

1) Struktur Wacana Kelas pada Pertukaran Bebas

Pertukaran bebas dalam proses pembelajaran terbagi ke dalam tiga kategori yaitu berupa pancingan, menginformasikan dan perintah atau arahan.

\section{a) Pertukaran Bebas Kategori Pancingan}

Pada pertukaran bebas kategori pancingan memiliki struktur yang berbeda jika dilihat dari pengambilan peran inisiasi di awal pembelajaran. Struktur yang dihasilkan dari inisisasi guru I R (F) sedangkan struktur yang dihasilkan oleh pancingan siswa I $R$ tanpa F. Dalam pertukaran yang dimulai dengan inisiasi guru, setelah mendapatkan respons dari siswanya la memilih memberika balikan dalam bentuk bahasa nonverbal berupak gerakan menganggukkan kepala sebagai tanda persetujuan respons dari siswa. Sedangkan dalam pertukaran yang diawali dengan inisiasi siswa, setelah guru memberikan respons siswa yang bersangkutan tidak memberikan balikan kepada guru sebagai tanggapan dari 
inisiasinya. Bahkan setelah merespons pertanyaan siswa guru juga tidak bertanya kembali apakah jawabannya sudah dipahami oleh siswa yang bersangkutan.

b) Pertukaran Bebas Kategori Menginformasikan

Struktur pertukaran bebas dengan kategori menginformasikan dengan inisiasi dipengang perannya oleh guru memiliki struktur pertukaran berupa I $R$ tanpa F. Dalam pembelajaran mengenai pola-pola pengembangan teks eksplanasi, guru hanya memberikan informasi yang dapat dilihat di salandia komputer siswa tanpa memberikan referensi materi yang lain. Sedangkan saat pertukaran bebas dengan siswa yang memberikan inisiasi. Siswa justru memberikan balikan dari respons yang diberikan. Pada pertukaran ini fungsi $F$ menjadi fungsi opsional saat inisiasi dilakukan oleh guru. Struktur ini sama dengan struktur wacana yang disampaikan oleh (Atkins, 2001:3) yang menyatakan bahwa F dapat hadir maupun tidah hadir dalam pertukaran karena bersifat opsional. Selaras dengan pernyataan (Nicholson, 2014:201) yang menyatakan salah satu struktur wacana kelas seperti tersebut di atas.

c) Pertukatan Bebas Kategori Perintah atau Arahan

Struktur kedua pertukaran kategori perintah dia atas memiliki struktur I R (F). Pertukaran diawali dengan inisiasi dari guru yang memberikan arahan atau perintah kepada siswa untuk membaca materi yang ada di slide halaman 17, setelah itu guru menanyakan pemahaman siswa dan siswa menjawab paham. Guru hanya memberikan contoh berdasarkan materi dalam slide, padahal materi tentang pola pengembangan ini dalam buku elektonik siswa atau buku (Kemendikbud, 2017:67). Meskipun punya buku pegangan sendiri guru tidak memberikan tambahan pengetahuan dari buku itu kepada siswanya. Kemudian, kebanyakan dalam proses pembelajaran saat ditanya oleh guru paham atau tidak identik siswa akan menjawab dengan kata paham, meskipun pemahaman siswa tersebut belum bisa diukur.

Pada saat inisiasi diambil oleh siswa, dalam kegiatan ini hanya melibatkan siswa satu dengan siswa lainnya tanpa ada pengaruh komunikasi dari guru. Salah satu siswa menggunakan bahasa daerah. Penggunaan bahasa ini tak terlepas 
dari keseharian mereka dalam berinteraksi dengan teman, maupun orang yang ada di sekeliling mereka.

2) Struktur Pertukaran Terikat

Pertukaran pengajaran yang berupa pertukaran terikat dalam pembelajaran ini memiliki tiga jenis struktur diantarannya adalah: struktur pertukaran terikat dengan modifikasi struktur dari struktur model awal. Struktur pertukaran terikat ini berupa 1) kategori inisiasi ulang, namun tidak menyertakan balikan pada akhir batas pembelajaran dan melakukan dua kali inisiasi ulang (lb); 2) pertukaran terikat berupa penguatan; dan 3) pertukaran terikat berupa pengulangan.

Bahasa yang digunakan guru dalam pembelajaran adalah bahasa Indonesia dalam penyampaian materinya ini sesuai dengan hasil penelitian dari (Wirma \& Suryadi, 2017:193) bahwa guru menggunakan bahasa Indonesia yang berfungsi sebagai bahasa pengantar keilmuan atau pendidikan. Namun, dalam tahap pertukaran dan gerak pembelajaran ada kalanya guru juga menggunakan bahasa daerah. Misalnya, guru mengucapkan kata mudeng, dengan tujuan memancing siswa untuk mengetahui dan memahami pola pengembangan proses dalam penyusunan teks eksplanasi. Selain guru, siswa juga masih menggunakan bahasa daerah dalam berkomunikasi dengan temannya. Pemakaian bahasa daerah ini tidaklah menyalahi aturan dari ketentuan Undang-Undang Nomor 24 Tahun 2009 yang intisarinya mengamanatkan masyarakat Indonesia untuk bisa mengutamakan bahasa Indonesia, lestarikan bahasa daerah, dan kuasai bahasa asing.

Menurut hasil observasi yang dilakukan sebelum penelitian, mayoritas siswa yang bersekolah di MA Al-Istiqomah dalam kesehariannya selalu menggunakan bahasa daerah, sehingga merasa asing dengan bahasa Indonesia sekalipun. Ini menjadi kenyataan yang miris, karena pembelajaran bahasa Indonesia sudah diajarkan dari taraf sekolah dasar hingga MA yang mereka tempuh dan sudah di tahun kedua. Tetapi mereka masih juga mengalami kesulitan dalam menerapkannya dalam berinteraksi dan berkomunikasi khususnya di dalam kelas saat proses pembelajaran sedang berlangsung. 


\section{b. Pola Komunikasi Wacana Kelas pada Pembelajaran Teks Eksplanasi}

1) Pola Komunikasi Dua Arah dalam Pembelajaran

Pola komunikasi dalam wacana kelas pada pembelajaran teks eksplanasi guru melakukan interaksi dengan salah atu siswa yang diawali dengan dua insiasi dan disertai dua respons. Pola komunikasi ini direalisasikan guru dan siswa dalam pembelajaran dengan langkah-langkah sebagai berikut.

1) Guru menampilkan salindia halaman delapan yang memuat materi tentang fungsi teks eksplanasi untuk memperluas wawasan, pengetahuan, dan keyakinan para pembaca ataupun pendengarnya.

2) Guru memberikan pertanyaan kepada siswa mengenai contoh-contoh fenomena yang ada di dalam teks eksplanasi.

3) Merasa pertanyaannya hanya direspons diam oleh siswa, guru langsung menampilkan slide berikutnya mengenai struktur teks eksplanasi, dan membacakan struktur tersebut di hadapan siswa. Materi ini jika dilihat dalam buku elektronik ada di halaman 57.

4) Setelah menampilkan struktur teks, guru memberikan inisiasi pertanyaan dengan maksud siswa diminta menjelaskan pada guru dan temantemannya mengenai struktur teks eksplanasi tersebut.

5) Dengan inisiasi guru tersebut salah satu siswa langsung mengangkat tangan dan menjawab pertanyaan sebagai responsnya.

6) Guru mendengar dan menerima jawaban siswa, tanpa memberikan balikan. Namun langsung memberikan kesempatan dan penawaran pada siswa lain untuk menjawab pertanyaan yang diberikan. Bahkan memberikan petunjuk untuk siswa jika ingin menjawabnya.

7) Siswa merespons pertanyaan itu dengan diskusi sesama siswa sehingga terdengar suara gaduh, melihat keadaan itu guru langsung memberikan instruksi kepada siswa untuk mengangkat tangan jika ingin menjawab.

8) Setelah menunggu beberapa waktu, tidak ada siswa yang menjawab. Guru memilih mengulangi lagi penyampaian pengambaran rangkaian kejadian yang terdiri dari rincian yang berpola pertanyaan bagaimana dan mengapa 
(inform). Lalu memberikan pertanyaan berupa contoh pola pertanyaan tersebut.

9) Siswa menjawab pertanyaan tersebut dengan dua jawaban menggunakan satu pola bagaimana.

10)Guru memberikan balikan dengan kata bagus disertai dengan anggukan kepala tanda setuju.

Pada komunikasi dan interaksi pembelajaran, tindak yang dilakukan oleh guru dan siswa memiliki perbedaan yang mendasar. Perbedaan tersebut dapat dilihat dari tindak yang dilakukan oleh guru berikut

1) Menyajikan atau menampilkan materi dengan salindia, dan membacakannya. Guru sebatas membacakan informasi saja.

2) Inisiasi yang diberikan guru berupa satu pernyataan berupa penyampaian materi dengan membacakan slide, dan empat pertanyaan yang ditujukan pada siswa.

3) Guru memberikan respons untuk jawaban siswa dan memberikan umpan balik pada salah satu jawaban siswa. Dari keempat pertanyaan yang disampaikan guru hanya memberikan satu kali umpan balik, dan memberikan respons kembali pada salah satu siswa yang meminta repons tersebut.

Sedangkan tindak yang dilakukan oleh siswa berupa: 1) merespons pertanyaaan dari guru. Dengan empat pertanyaan dari guru hanya tiga pertanyaan yang mendapat respons dari siswa. Kemudian, 2) mendapat respons balasan dan penerimaan. Siswa mendapat respons atas pertanyaan dan mendapat jawaban dari guru berupa penerimaan.

Pola komunikasi dua arah juda dapat dilihat dalam kegiatan diskusi siswa dengan siswa lain yang tidak melibatkan peran guru dalam pelaksanaannya. Hal ini dapat dilihat sebagai berikut.

104 S: S16, S15 dan S14 Diskusi tentang Rangkuman.

105 S14 : Ditulis dan dijelaskan semua yo (el)? Riski, iki ditulis ko iki (el). Menunjuk slide ketujuh.

106 S15 : Dijelaskan secara detail tapi singkat, tidak terlalu panjang lebar dan menggunakan bahasa Indonesia (e). 
Dalam pertukaran tersebut ada tiga siswa, namun hanya dua yang melakukan iteraksi timbal balik. Komunikasi ini mendiskusikan mengenai perintah guru untuk membuat rangkuman. Namun entah mengapa, mereka justru memilih berdiskusi kecil dari pada bertanya langsung dengan gurunya. Seharusnya sesudah guru memberikan perintah, harusnya dilihat kembali. apakah yang diperintahkan itu sudah dipahami maksudnya oleh siswa. Dengan begitu, siswa akan mantap dalam melaksanakan tugasnya.

2) Pola Komunikasi Banyak Arah

Pola komunikasi banyak arah ada banyak partisipan dalam berkomunikasi diantaranya yaitu interaksi guru dengan keempat siswa serta beberapa siswa yang memberikan tanggapan secara serentak. Dalam hubungan ini terjalin komunikasi pada banyak pihak, pihak guru ke siswa, siswa ke siswa serta siswa ke guru.

Proses pembelajaran diawali dengan guru memberikan instruksi untuk membuat rangkuman materi pembelajaran dari awal sampai materi terakhir. Yaitu dari mulai definisi sampai dengan contoh cara menentukan bagian-bagian teks. Instruksi ini akan menjadi indikator bahwa siswa benar-benar paham dengan materi yang dibaca dan dipelajarinya. Yang menarik dalam komunikasi ini adalah tanggapan atau respons siswa yang secara serentak memberikan tanggapan kepada pertanyaan salah satu siswa. Siswa juga memberikan tawaran dalam mengerjakan tugas yang disampaikan oleh guru dan memberatkannya, namun guru dengan telaten dan sabar memberikannya solusi dengan tindak nyata demi meringankan tugas siswa tersebut. Selain itu transaksi dengan pola komunikasi banyak arah dapat dilihat dalam diskusi kelompok dari beberapa siswa berikut:

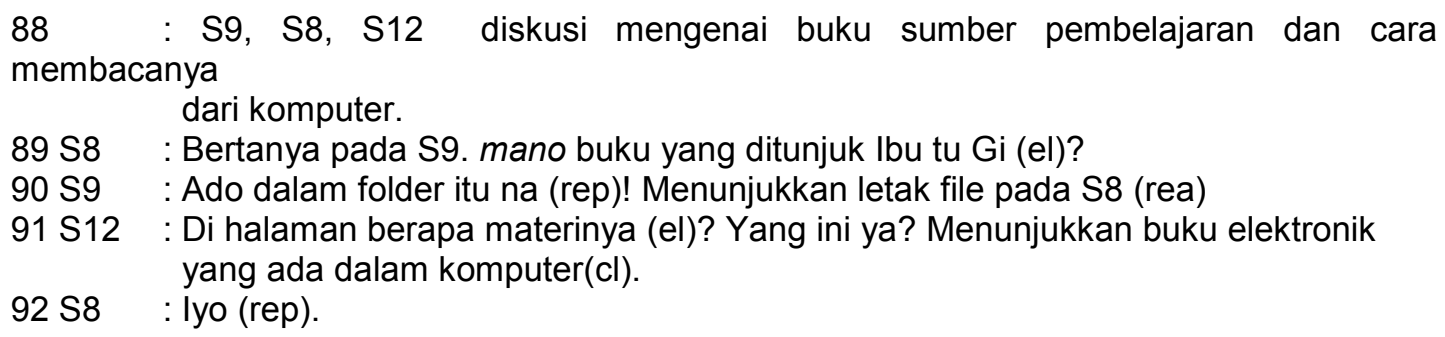

Transaksi dilakukan oleh tiga siswa tanpa campur tangan guru. Transaksi ini mengahasilkan pertukaran berupa diskusi mengenai buku rujukan yang 
disampaikan oleh guru. Dari pertukaran ini, seluruh tindak dilakukan oleh siswa. Dari mulai menghasilkan inisiasi, respons maupun balikan. Salah satu kajian yang disampaikan oleh Tsui (2008:2) bahwa analisis wacana kelas mengacu pada semua bentuk interaksi yang terjadi di dalam kelas. Baik interaksi antara guru dan siswa maupun siswa dan siswa. Pada pembelajaran dengan subjek dalam jumlah banyak, maka interaksi yang terjalin akan semakin beragam. Pola komunikasi atau interaksi ini berjalan dua arah, antara satu siswa dengan siswa lain. Ada pergantian penutur yang teratur dalam kelompok kecil yang sedang berdiskusi. Dan pola komunikasi ini tidak ada dalam model asli analisis wacana kelas tradisional Sinclair dan Coulthard (dalam Tsui, 2008:3).

Gerak dan tindak dalam analisis wacana kelas pada pembelajaran teks eksplanasi berjalan beriringan dalam mengasilkan pertukaran pengajaran. Gerak yang dilakukan yaitu gerak membingkai dan memfokuskan, lalu menginisiasi, merespons dan memberikan umpan balik atau balikan. Sedangkan tindak, khususnya tindak tutur memiliki lebih banyak variasi yang dihasilkan. Berdasarkan data pada tabel 8 tentang kategori tindak tutur, dapat dilihat bahwasannya tindak yang paling sering dilakukan oleh guru dalam proses pembelajaran teks eksplanasi adalah tindak permulaan, pancingan, informatif, dan penilaian. Sedangkan tindak yang paling dominan dilakukan oleh siswa adalah membalas atau menjawab, menggunakan insyarat atau bahasa nonverbal dan tawaran. Tidak jauh berbeda dari hasil penelitian yang dilakukan oleh (Saptani, 2015:8). Namun pada penelitian terdahulu, tindak tutur yang dominan adalah arahan (directive), pancingan (elicitation), menjawab atau membalas (reply), dan penunjukan (nomination). Hanya pada tindak tutur elicitation yang sama-sama dominan. Tindak tutur yang dominan dilakukan oleh guru dalam proses pembelajaran teks eksplanasi: 1) pengantar/permulaan (starter), tindak tutur starter ini hanya dilakukan oleh guru dalam pembelajaran. Pada pembelajaran teks eksplanasi ini tindak starter yang dilakukan oleh guru sebanyak 10 kali. Permulaan yang dilakukan oleh guru ada yang berupa pernyataan dan ada juga yang berupa pertanyaan. 2) Pancingan atau pemunculan (elicitation), tindak tutur ini disimbolkan dengan 'el', yakni sebuah pertanyaan yang berfungsi untuk 
meminta respons bahasa. Dalam pembelajaran tindak tutur ini bisa disampaikan oleh guru dan juga bisa dilakukan oleh siswa. Dalam pembelajaran teks eksplanasi ini tindak tutur elicitation memiliki frekuensi cukup tinggi, yaitu muncul 27 kali yang disampaikan guru dan 8 kali. 3) Informasi (inform), tindak tutur ini disimbolkan dengan 'i', yakni sebuah berupa pernyataan yang berfungsi untuk memberikan informasi. Satu-satunya respons adalah pengakuan atas perhatian atau pengertian. Dalam pembelajaran tindak tutur ini bisa disampaikan oleh guru dan juga bisa dilakukan oleh siswa. Dalam pembelajaran teks eksplanasi ini tindak tutur inform memiliki frekuensi cukup tinggi, yaitu muncul 14 kali dengan 13 disajikan oleh guru dan satu lagi disampaikan oleh siswa. Sementara, tindak tutur dominan yang dilakukan oleh siswa adalah reply (menjawab atau membalas, cue (isyarat), dan react (reaksi).

Tindak tutur ini disimbolkan dengan 'rea' fungsinya untuk memberikan respons non-linguistik yang sesuai dengan arahan sebelumnya dalam tuturan. Misalnya memberi reaksi, respons yang bersifat non-linguistik terhadap pengarahan guru (mengangguk, menggeleng, dsb.). Dalam pembelajaran teks eksplanasi ini reaksi yang dilakukan oleh siswa sebanyak 8 kali dengan 3 kali dari guru dan 5 kali dari siswa.

Dilangkah terakhir dalam pembelajaran guru tidak memberikan tes formatif atau menguji keberhasilan pembelajaran dengan mengecek pemahaman siswa. Meskipun pada saat proses pembelajaran berlangsung, guru memberikan instruksi untuk membuat rangkuman materi pembelajaran dari awal sampai akhir pembelajaran. Guru mengecek hasil rangkuman siswa hanya dengan melihat dan membaca sekilas di meja siswa yang didekatinya (dan tidak semua siswa dilihat hasil kerjanya). Dengan tes tersebut akan dapat dilihat keberhasilan atau ketidakberhasilan pembelajaran yang dilakukan.

Selain itu guru juga tidak menyampaikan kesimpulan hasil pembelajaran yang telah dilakukan dari mulai awal sampai akhir pembelajaran. Bahkan sebelum menutup pembelajaran atau proses belajar, guru tidak menyampaikan materi yang akan dibahas pada pertemuan yang akan datang. Guru juga tidak memberi tugas atau latihan yang harus diselesaikan atau dikerjakan. 


\section{Simpulan dan Saran}

Kesimpulan dalam penelitian analisis wacana kelas ini sebagai berikut:

1. Struktur wacana kelas pada pembelajaran teks eksplanasi di Madrasah Aliyah Al-Istiqomah tidak selalu berstruktur I R F pada pertukaran bebas. Adakalanya F menjadi opsional, atau tidak ada dalam melakukan pertukaran bebas. Sedangkan pada pertukaran terikat fungsi F tidak hanya menjadi balikan, namun disertai inisiasi ulang atau terikat (Ib) sehingga struktur wacana kelasnya menjadi I R Ib R F/lb R.

2. Pola Komunikasi pada Pembelajaran Teks Eksplanasi

a). Pola Komunikasi sebagai Interaksi

Tindak tutur yang paling sering dilakukan dalam berinteraksi oleh guru pada proses pembelajaran teks eksplanasi adalah tindak permulaan, pancingan, informatif, dan penilaian. Sedangkan tindak yang paling dominan dilakukan oleh siswa adalah membalas atau menjawab, menggunakan insyarat atau bahasa nonverbal dan tawaran.

b) Pola Komunikasi sebagai Transaksi

Pada pelaksanaan pembelajaran teks eksplanasi, tujuan pembelajaran tidak terpenuhi karena guru hanya menyajikan materi pembelajaran yang telah disediakan pada komputer, tanpa memberikan pemahaman atau contoh lain selain dari slide yang disajikan. Penggunaan komputer belum dimaksimalkan oleh guru, sehingga penampilan salindia hanya satu tipe atau model saja.

Dari hasil proses pembelajaran, maka peneliti memberikan saran kepada guru yang mengajar yaitu: lebih teliti dalam merumuskan tujuan pembelajaran dan menerapkan langkah untuk mencapai tujuan dengan memberikan tes sumatif kepada siswa, dapat menyampaikan materi dengan lebih ekspresif dan kreatif, serta lebih memaksimalkan fungsi media dan sumber materi pembelajaran. 


\section{Daftar Pustaka}

Apreno, R., \& Noermanzah, N. (2020). Ideologi Kapitalisme dalam Iklan Rokok Djarum 76 Edisi Wani Piro: Kajian Analisis Wacana Kritis. Silampari Bisa: Jurnal Penelitian Pendidikan Bahasa Indonesia, Daerah, dan Asing, 3(1), 93. doi:10.31540/silamparibisa.v3i1.882

Atkins, A. (2001). Sinclair and Coulthard's 'IRF' Model in a One-to-One Classroom: an Analysis. https://www.birmingham.ac.uk/Documents/collegeartslaw/cels/essays/csdp/Atkins4.pdf

Darma, Y. A. (2009). Analisis Wacana Kritis. Bandung: Yrama Widya.

Handayani, T. R. M., Trianto, A., \& Ariesta, R. (2020). Analisis Wacana Kelas dalam Pembelajaran Bahasa Indonesia pada Pelaksanaan Debat Kelas X SMA Negeri 09 Kota Bengkulu Tahun Ajaran 2019. Jurnal IImiah KORPUS, 4(1), 108-117. doi:10.33369/jik.v4i1.8354

Kemendikbud. (2017). Buku Guru Bahasa Indonesia SMA/MA/SMK/MAK Kelas XI. Jakarta: Pusat Kurikulum dan Perbukuan, Balitbang, Kemendikbud.

Kemendikbud. (2017). Buku Siswa Bahasa Indonesia SMA/MA/SMK/MAK Kelas $X I$. Jakarta: Pusat Kurikulum dan Perbukuan, Balitbang, Kemendikbud.

Nicholson, S. J. (2014). An Impetus for Change: Classroom Analysis Using Sinclair and Coulthard's Model of Spoken Discourse. International Journal of Linguistics, 6(2), 199-219.

Noermanzah, N., Abid, S., \& Septaria, S. (2018). Improving the Ability of Writing a Narrative Charge by Using Animated Images Media Student Class V.B SD Negeri 17 Lubuklinggau. BAHTERA : Jurnal Pendidikan Bahasa dan Sastra, 17(2), 116. doi:10.21009/bahtera.172.9

Normawati. (2017). Kemampuan Menulis Teks Eksplanasi Siswa Kelas XI IPA2 SMA Negeri 1 Sentani Kabupaten Jayapura. Kibas Cenderawasih, 14(2), 221236.

Saptani, P. (2015). Tindak Tutur dalam Wacana Kelas Vb SD Negeri 62 Kota Bengkulu Tahun Pelajaran 2012/2013. Diksa : Pendidikan Bahasa dan Sastra Indonesia, 1(2), 1-8. doi:10.33369/diksa.v1i2.3145.

Sugiyono. (2018). Metode Penelitian Kualitatif. Bandung: Afabeta.

Sukmadinata, N. S. (2008). Metode Penelitian Pendidikan. Bandung: Remaja Rosdakarya. 
Tsui, A. (2008). Classroom Discourse: Approaches and Perspectives. Classroom Interaction / ABMT , 1-12. http://hdl.handle.net/10722/57046

Undang-Undang Nomor 24 Tahun 2009 tentang Bendera, Bahasa, dan Lambang Negara serta Lagu Kebangsaan.

White, A. (2003). The Application of Sinclair and Coulthard's IRF Structure to a Classroom Lesson: Analysis and Discussion. University of Birmigham , 1-17.

Wirma, S., \& Suryadi, B. D. (2017). Analisis Wacana Interaksi Kelas Bahasa Guru dalam Pembelajaran Bahasa Indonesia di Kelas VII B SMPN 11 Kota Bengkulu Tahun Ajaran 2016/2017. Jurnal IImiah Korpus, 1(2), 191-198.

Silampari Bisa: Jurnal Penelitian Pendidikan Bahasa Indonesia, Daerah, dan Asing Vol. 3, No. 2, 2020 